\title{
Functional alterations of the autonomic nervous system in Chagas' heart disease
}

Division of Cardiology, Department of Internal Medicine, Faculdade de Medicina de Ribeirão Preto da Universidade de São Paulo - São Paulo, Brazil

\begin{abstract}
Several independent pathological studies in experimental models and in human beings showed conspicuous autonomic denervation in Chagas' disease. In spite of the inherently complex structural organization of the autonomic nervous system, the parasympathetic and sympathetic divisions are involved, as shown by many functional studies. Hence, Chagas' disease represents a unique model of impairment of the autonomic control of the heart, in absence of the nonspecific effects of cardiac

failure. An important limitation of the studies thus far carried out is the lack of a better knowledge of the molecular biology characteristics of different strains of $T$. cruzi. This could explain some geographical discrepancies found in the clinical behaviour of Chagas' disease, and contribute to a better understanding of its pathophysiology.
\end{abstract}

UNITERMS: Chagas' disease. Autonomic nervous system.

\section{INTRODUCTION}

$\mathrm{S}$ ince the primordial studies by Carlos Chagas and coworkers, the pathological involvement of the nervous system in the trypanosomiasis discovered by him has been the subject of research and speculation (14). The existence of a nervous form characterized by central manifestations of neuropathy, including psychiatric disorders, has indeed been proposed (75); however, this

\author{
Address for correspondence: \\ Dalmo de Souza Amorim \\ Faculdade de Medicina de Ribeirão Preto da \\ Universidade de São Paulo \\ Divisão de Cardiologia - Departamento de Clínica Médica \\ Ribeirão Preto - SP - Brasil - CEP 14049-900
}

form did not receive definitive clinical acceptance despite the fact that it was specifically investigated in studies using different methodological approaches. Nevertheless, not only it is possible to detect anatomically polyfocal aggressions against the central nervous system, but there are studies demonstrating a certain degree of sensorimotor functional impairment detected by laboratory tests in patients with Chagas' disease $(57,67)$.

There is ample evidence that Chagas' disease as characterized by a marked preference for involvement of the muscle and nervous systems $(35,36)$. In this respect, the physiopathology of several clinical syndromes associated with Chagas' disease, such as cardiopathy, esophagopathy, colopathy etc., should logically involve essentially muscular and nervous lesions in the corresponding organs. Thus, the involvement of the neurovegetative system seems to be the essential element in the digestive manifestations of the disease, with a 
predominance of this mechanism over the concomitant direct myopathic process in the esophagus and colon $(36,52)$.

However, the mechanisms responsible for triggering and installation of the muscular and nervous lesions detected during the acute and chronic phases of the disease have not been sufficiently clarified. Furthermore, the physiopathological role of the nervous lesions documented in Chagas' disease continues to be controversial, especially with respect to Chagas' heart disease.

\section{ANATOMICAL DEMONSTRATION OF AGGRESSION AGAINST THE PARASYMPATHETIC SYSTEM OF THE HEART}

On the basis of the results obtained in autopsy studies at several independent centers, it is possible to conclude that lesions of the intracardiac nervous system are practically constant in human trypanosomiasis occurring in Brazil $(35,36,54,55)$. These lesions diffusely involve the cardiac nervous structures, although they are characterized by their peculiar focal nature of irregular and unpredictable distribution. Systematic evaluations using light and electron microscopy have demonstrated degenerative lesions in subpepicardial ganglia, in Schwann and satellite cells, and in myelinic and amyelinic nerve fibers deep inside the myocardium $(54,72)$.

In order to quantify the extent of parasympathetic denervation in the chagasic heart, Köberle and collaborators adopted, starting in the 1950's, techniques of neuronal counting based on exhaustive and standardized microscopic exploration of serial histological sections obtained from the so-called intercaval atrial band $(8,36,55)$. This method permitted the definite detection of cardiac neuron depopulation in autopsied chagasics. Different quantitative methods exploring other anatomical regions of the heart adopted by independent researchers confirmed the indisputable reduction of atrial intramural neurons in individuals who had died during different phases, or with different forms of Chagas' disease $(42,54,64,72)$. Since the beginning, extreme variability in individual neuronal counts was observed in autopsied chagasics. There were cases in which destruction appeared to be total (not a single intact neuron was found), side by side with cases in which the number of nervous cardiac cells was within the limits usually detected in "normal" controls $(54,72)$.
On the other hand, although this atrial (parasympathetic) neuronal depopulation cannot be considered an attribute of Chagas' disease alone, in all comparative studies with other diseases such as rheumatism $(39,64)$, endomyocardial fibrosis (10), dilated cardiomyopathy $(8,10)$ and hypertensive heart disease $(39)$, the phenomenon was found to be much more conspicuous in Chagas' heart disease (Fig. 1). Another important feature of the parasympathetic neuronal depopulation of chagasic etiology is the absence of a correlation between the intensity of denervation and other cardiac anatomopathological characteristics (15), the type of death (sudden, during cardiac failure) (40) or the clinical phase (form) of the disease at the time of death (41). As an exception to this rule, only with respect to the concomitance of digestive involvement (megaesophagus and/or megacolon), a significant correlation with the intensity of cardiac parasympathetic depopulation has been recorded (2).

Apparently, it was only in a systematic study of the cardiac parasympathetic nervous system carried out in

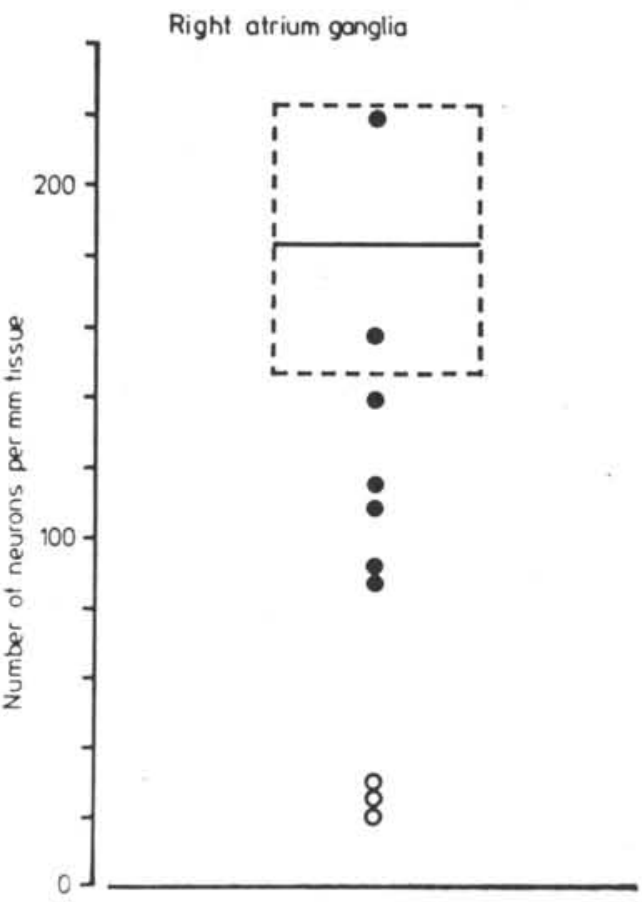

Figure 1. Number of ganglion cells per $\mathrm{mm}$ of right atrial tissue. The full line is the average and the dashed lines are the standard deviations for five control hearts from adults aged $44.0 \pm 6.0$ years. The solid circles indicate individual values for seven patients with dilated cardiomyopathy, while the open circles reveal very low neuronal count in three chagasic hearts. (FromAmorim and Olsen, $\left.1982^{13}\right)$. 
Venezuela (70), that the phenomenon of neuronal depopulation in autopsied chagasics was denied. According to that study, there may be a mild fiber degeneration without a significant reduction in number of neurons. It should be pointed out that, at least with respect to quantitative aspects, these investigators probably made the mistake of counting only ganglia and not actual neurons. Other possibilities that may eventually explain this discrepancy between the study in question and the others will be analyzed further on.

The experimental studies carried out on various animal models of laboratory infection with $T$. cruzi may be considered to confirm qualitatively and quantitatively the aggression of chagasic etiology against the intracardiac nervous structure $(22,71)$. However, two additional relevant aspects emerge from these studies: a) electron microscopy and histochemical techniques demonstrate the generalized occurrence of pathological involvement of atrial cardiac nervous structure in terms of anatomical and functional damage in acutely infected mice (71); b) the potential for aggression against cardiac ganglionic structures and myenteric nervous plexuses appears strongly to depend on the parasite strain used to produce chagasic infection and on its particular interaction with the inoculated host (65). To illustrate, in studies on chronic infection in mice, the $\mathrm{Y}$ strain proved to be much more pathogenic for the colonic Auerbach plexus than the Colombia strain, and the neuron-damaging potential of the Berenice strain appeared to be greater than that of the $\mathrm{ABC}$ strain, whereas strains isolated in the region of the Brazilian Bahian "Recôncavo" seem to present low virulence against the nervous structures of the digestive tube (9). In another study, the $\mathrm{Y}$ and Bolivia strains showed greater neuron-destroying ability than the PF strain (65).

\section{FUNCTIONAL REPERCUSSIONS OF PARASYMPATHETIC CARDIAC DAMAGE}

The original papers by Carlos Chagas and collaborators mention a peculiar absence of the chronotropic response to the vagolytic agent atropine in chagasic patients: "On the basis of a large number of cases, we conclude that the dromotropic action of this drug is quite considerable and that its habitual chronotropic action is very small in many cases". "In the presence of complete blockade, the dromotropic action of the drug was absent. In the same cases, the chronotropic action was of low intensity and was often in the negative direction, i.e., it caused the paradoxical effect of reducing the number of auricular beats" (14).

In 1955, A. Brasil again pointed out, as part of the so-called "autonomic sinoatrial blockade", the ineffectiveness of atropine in inducing tachycardia in chronic chagasic patients (12).

Among these original studies were those on the participation of nonspecific mechanisms of depression of cardiac vagal control linked to cardiac failure of any etiology $(17,29)$. Starting in the 1960 's, an extensive series of studies was undertaken in the Laboratory of Cardiac Catheterization of the Faculty of Medicine of Ribeirão Preto. The studies were carried out on chagasic patients carefully selected on the basis of the absence of current or previous manifestations of heart failure and demonstrated that chronic chagasic patients show:

a) an abnormal response to pharmacological inhibition of the efferent cardiac parasympathetic system (non-evoked sinus tachycardia, like in normal individuals, by intravenous atropine administration) $(5,48)$ (Fig. 2).

b) Abnormal response to reflex inhibition by physiological stimuli of the efferent cardiac parasympathetic system (deficient sinus tachycardiac response during the phase of hypotensive compression of the Valsalva maneuver (44), at low-intensity levels of

HEART RATE RESPONSES TO ATROPINE $0.04 \mathrm{mg} / \mathrm{kg}$ IV

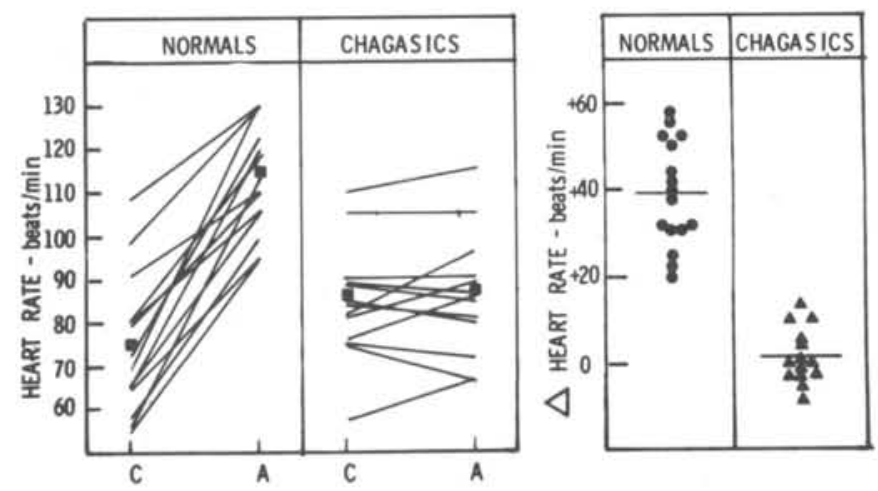

Figure 2. Effects of atropine sulfate on heart rate (peripheral venous administration at the dose of $0.04 \mathrm{mg}$ per kilo). Values prior to $(C)$ and following vagal blockade $(A)$. Absolute values (left panel) and individuals changes (right panel). (From MarinNeto et al., $\left.1986^{33}\right)$. 


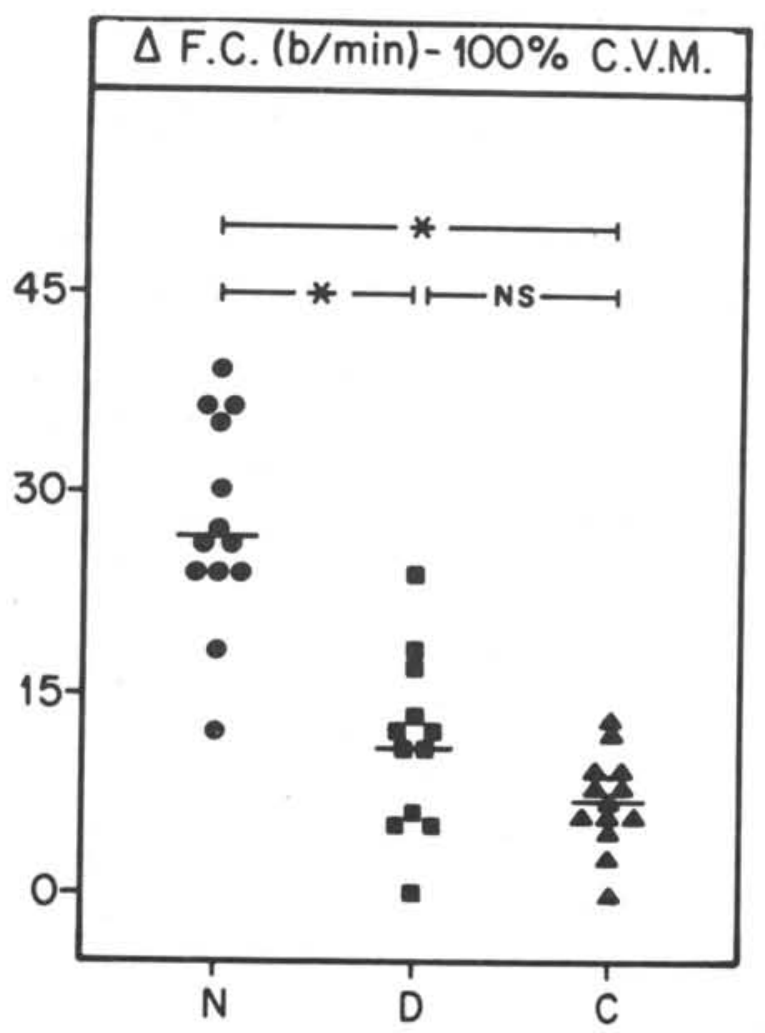

Figure 3. Heart rate responses during isometric exercise in normal subjects $(N)$, chagasic patients with the digestivepathology (D) and patients with chronic Chagas heart disease. Both groups of patients had lower chronotropic responses (beats/min) per maximal voluntary contraction. (From Sousa, ACS et al., 1987 ${ }^{66}$ ). continuous dynamic effort with progressive loads (26), immediately after passive alteration of body position $(47,48)$, during the execution of an isometric effort (47) (Fig. 3) and during the early moments of chronotropic adjustment at each phase of a dynamic effort with a discontinuous protocol of increasing intensity (28).

c) Abnormal response to reflex excitation of the cardiac efferent vagal component by pharmacological means (absence of sinus bradycardia during systemic arterial hypertension provoked by infusion of metaraminol (Fig. 4) and by intravenous injections of phenylephrine) $(5,33)$ (Fig. 5).

d) Abnormal response to reflex stimulation of the cardiac efferent parasympathetic component by physiological methods (absence of sinus bradycardia during systemic arterial hypertension induced in the decompression phase of the Valsalva maneuver (44), or by head down positioning from an upright position (47), and during the reflex stimulus caused by face immersion) (25).

e) Reduction of the magnitude of sinus arrhythmia depending on the respiratory cycle according to a rigorously standardized method based on system analysis techniques $(27,50)$.

f) Significant decrease of the potency of night and morning chronotropic variability of both the low-frequency and high-frequency components, demonstrated by spectral analysis of the electrocardiographic Holter recording $(18,19)$ (Fig. 6).
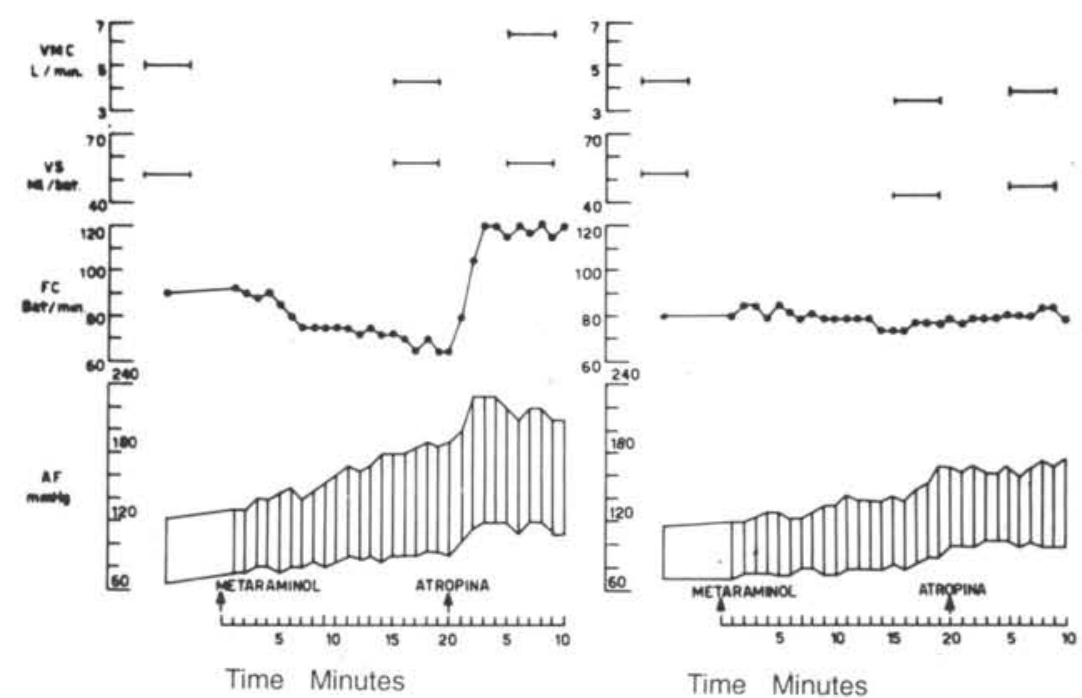

Figure 4. Metaraminol was injected into the peripheral venous circulation at a rate that would cause an increase of nearly $50 \mathrm{mmHg}$ in the systemic arterial pressure. At the height of blood pressure response $1 \mathrm{mg}$ of atropine sulfate was injected rapidly into the central venous circulation. Repeated measurements of cardiac output by indicator-dilution method. The normal subject (left panel) showed bradycardia during induced arterialhypertension, followed by tachycardia after vagal blockade. The chagasic patient (right panel) had no alterations in heart rate throughout these pharmacological interventions. (From Amorim, DS et al., 1968 ${ }^{28}$ ). 


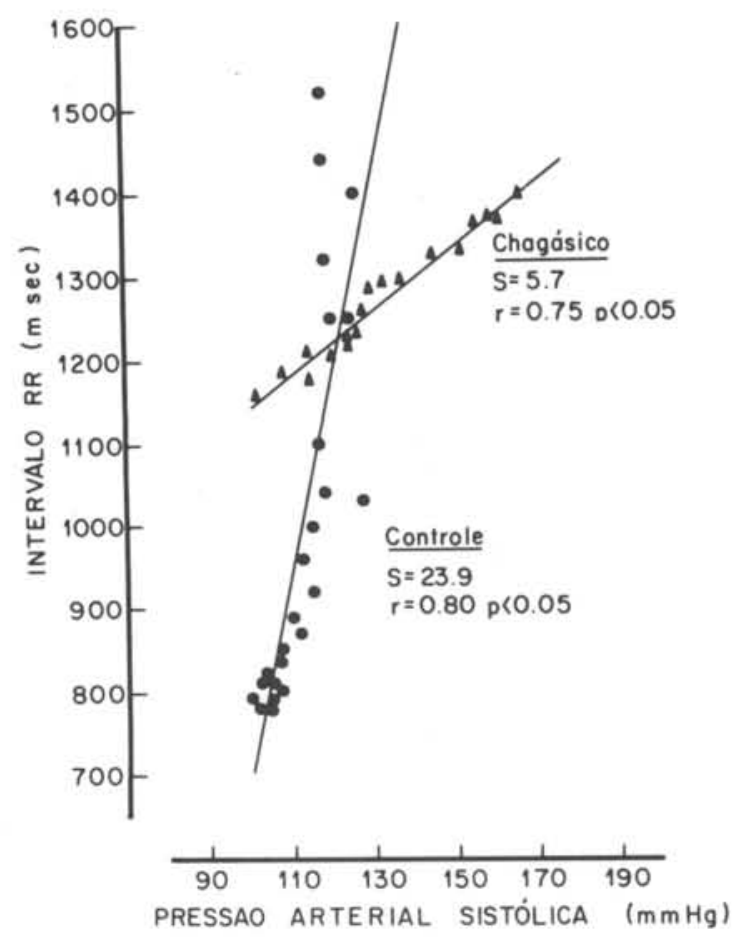

Figure 5. Baroreceptor sensitivity (S) evaluated by changes in systemic arterial pressure related to subsequent R-R intervals, following peripheral venous administration of phenylephrine. As compared to the control subject, the baroreceptor sensitivity is depressed in the chagasic patient.

Taken together, these alterations indicate that: a) many chagasic patients are deprived of the inhibitory action tonically exerted by the parasympthetic system on the sinus node of normal individuals; b) even more significantly, these chagasic patients do not have a rapid bradycardiainducing mechanism depending on the parasympathetic system for the reflex modulation of the transitory increases in systemic arterial pressure habitually observed under physiological or pathological conditions.

The above results are consistent with those obtained in studies conducted in Cordoba, Argentina, since the 1970 's using methods such as Valsalva maneuver, injection of phenylephrine, passive postural alteration, acute atropinization, and quantification of respiratory sinus arrhythmia $(13,61)$. According to the studies published in the literature, only the investigation conducted in Panama did not detect dysfunction of cardiac parasympathetic control in Chagas' disease (31).

\section{ANATOMICAL DEMONSTRATION OF AGGRESSION OF CHAGASIC ETIOLOGY AGAINST THE SYMPATHETIC SYSTEM}

The sympathetic system has been studied much less extensively than the parasympathetic system in Chagas' disease.

Exploration of the sympathetic system in experimental models of $T$. cruzi infection preceded the detection of lesions of adrenergic structures in autopsied humans. It first appeared that no numerical neuronal reduction occurred in the solar plexus of chronic chagasic rats (21). Several independent investigations later reported sympathetic denervation in chagasic animals with laboratory infection in the acute and chronic phases of infection with the $\mathrm{Y}$ strain. This denervation was detected in mice $(24,74)$, in the inferior hypogastric plexus of rats (16), and in the juxtaprostatic plexus of guinea pigs (23). Again, the type of strain used seems to play a decisive role in the triggering of neuronal lesions, with different degrees of parasitic tropism having been characterized for these structures. Aggression of chagasic etiology against the sympathetic system was anatomically documented in autopsy material in the early 1970's (1). A mean 37\% depopulation was detected in the cervical-thoracic ganglia, which are indeed those that project synapses towards the heart. It should be pointed out that the parasympathetic denervation detected in the same chagasic cadavers was of the order of $52 \%$.

\section{FUNCTIONAL REPERCUSSIONS OF CARDIOVASCULAR SYMPATHETIC DAMAGE}

A functional involvement of the cardiac sympathetic system was first suspected in studies in which deficient reflex tachycardia was detected in the presence of systemic arterial hypotension. Although these chronotropic deficiencies were first demonstrated in patients with Chagas' heart disease with a history of heart failure, they were later detected also in the absence of such a history (44). It should be pointed out that, when parasympathetic denervation occurs, deficient reflex tachycardia during a transitory period of arterial systemic hypotension cannot be imputed to depression of the adrenergic system: under such circumstances there may be reduced tachycardia during the compression phase of the Valsalva maneuver 

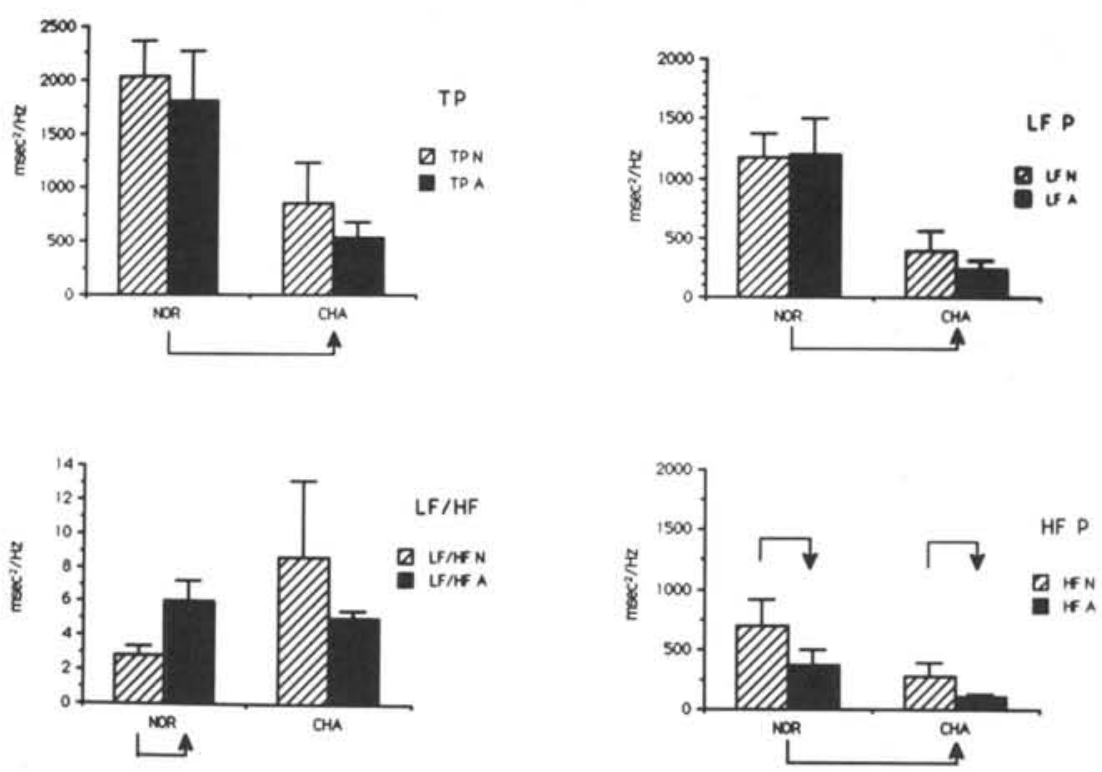

Figure $\overline{6}$. Twenty-four hours spectral variability of cardiac rate recorded in control subjects (N R) and in chronic chagasic patients (NA). Mean and standard deviation for the two groups. Hatched and block bars indicate sleeping (nightime) and awakened (daytime) values, respectively. Clockwise from upper left: TP (total power), LFP (low frequency power), HFP (high frequency power) and LF/HF (ratio low/high frequency). Chagasic patients showed lower values than normals, in addition to the lack of expected LF/HF ratio awakening. (From Endin, M, et al, 199241).

or during inhalation of amyl nitrite because there is no parasympathetic tonus to be liberated in a reflex manner, and the chronotropic response will then depend exclusively on sympathetic stimulation, inevitably becoming of smaller magnitude (45).

On the other hand, in early and recent studies on chagasic patients with various forms of the disease but with no cardiac failure, no deficiency of adrenergic response to dynamic physical exercise was detected $(26,28)$. A loss in the linearity of the chronotropic response only occurs at low-intensity exercise levels, predominantly consisting of removal of the inhibitory vagal tonic effect on the sinus node (26). With higher workloads, the increase in heart rate provoked by dynamic exercise in chagasic patients became superimposable to that of normal individuals, thus preventing the demonstration of sympathetic depression in Chagas' disease by this method.

However, following in the path first indicated by Carlos Chagas the test of passive changes of body position was used to evaluate the cardiac sympathetic system $(45,46,47)$. It was first observed that the elevation in heart rate evoked by the standing position is indeed biphasic: the initial response occurring during the first few seconds depends on the liberation of the sinus node from the vagal inhibition present in the supine position. After a few minutes in the upright position, the heart rate continues to be high predominantly by adrenergic stimulation of the sinus node (46). The standing responses observed in a group of normal individuals were compared to those of a chagasic group in the control condition and after selective blockade of the parasympathetic system with atropine and of the sympathetic component with propranolol. Chagasic patients with parasympathetic depression present a clearly impaired initial response both in the control condition and after abolition of the adrenergic system by blockade with propranolol. With the vagal system abolished by the action of atropine, the initial responses become predictably identical and depressed in both groups. As to the delayed adrenergic-dependent effect, chagasic patients can be distinguished from normal individuals both in the control condition and after atropine blockade: with the vagal mechanism blocked in both groups, the persistence of discrimination can only be unequivocally imputed to depression of the adrenergic mechanism of sinus node control present in patients with Chagas' heart disease (46) (Fig. 7).

In the studies cited above, it was never possible to detect abnormalities related to autonomic vascular control. In other words, the behavior of systemic arterial pressure in response to the administration of agents that reduce or elevate vascular resistance during dynamic or isometric physical effort, during the execution of the Valsalva 
maneuver and even during passive postural tests, could never be distinguished in a statistically significant manner between chagasic patients and normal controls $(5,33)$.

However, even with the use of tilting tests and, more recently, of the hyperventilation test, studies carried out in Cordoba, Argentina, have demonstrated patterns of diastolic pressure response differing from those observed in normal controls and compatible with the presence of a certain degree of sympathetic cardiovascular dysfunction in chagasic patients $(32,59)$. According to these studies, the deficient adrenergic vasomotor regulation, taken together with frequently reduced levels of basal heart rate, may explain the significantly lower systemic tension levels detected in the chagasic population when compared to normal groups (60).

It should be emphasized that, in contrast to what occurs in other disorders with generalized involvement of the neurovegetative system (for example, diabetes mellitus (21), Andrade amyloidosis (24) etc., in Chagas' disease there is no true clinical syndrome of cardiovascular dysautonomy with standing hypotension, intolerance of dynamic physical effort, or the characteristic pattern of pressor response to the Valsalva maneuver.

The discrepant features obtained in the investigations discussed above clearly illustrate the difficulty inherent in obtaining more in-depth knowledge about the physiopathology of the sympathetic system in general and in Chagas' disease in particular. Indeed, the structural organization of this autonomic division itself is intrinsecally more complex than that of the parasympathetic component, with the sympathetic chain presenting an extensive diffusion of ganglionic and postganglionic internuncial connections. The sympathetic ganglionic neurons (in contrast to the parasympathetic ones that are lodged deeply inside the innervated organ), are located at a distance and branch out widely, with their interconnections with other neurons and with many receptors being characterized by countless postganglionic fibers. In contrast, the parasympathetic anatomical arrangement depends on a discrete degree of branching, with a proposed basic scheme of neurons selectively connected with each receptor by postganglionic fibers separately linked to the synaptic plate. Furthermore, the cholinergic mediator must obligatorily act at the site of release since the catalytic system of cholinesterase has a rapid and intense inactivating effect. Conversely, despite the presence of cellular and extracellular enzymes such as COMT and MAO, the adrenergic mediators circulate at concentrations sufficient to permit an important action at a distance from their site of release. These distinctive characteristics of both systems may explain the greater facility in detecting evidence of parasympathetic function than evidence of depression of the sympathetic component in Chagas' disease, a disorder known to induce diffuse damage to the autonomic system.

We may speculate, for example, that the use of dynamic exercise, by representing very intense activity capable of inducing very strong and diffuse stimulation of
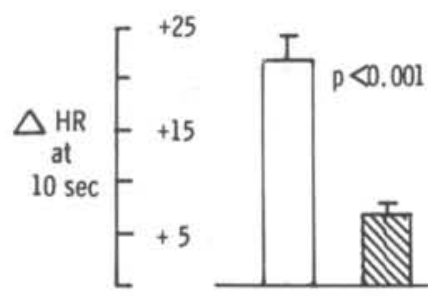

NS $\quad p<0.001$
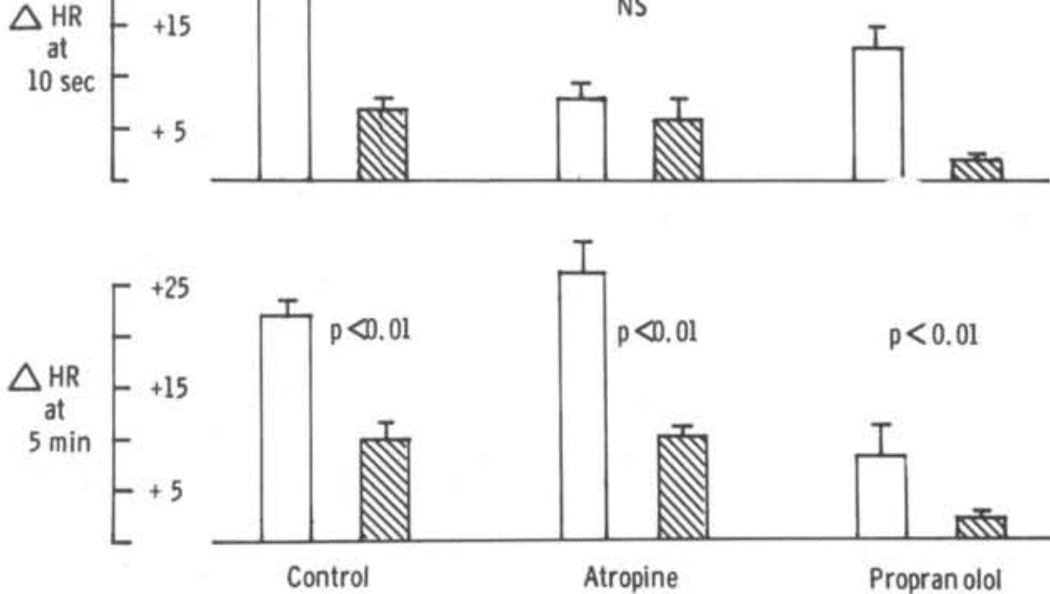

Figure 7. Chronotropic responses during passive changes in body position ("tilting test") recorded in normals (open bars) and chagasic patients (hatched bars), under control situation and following intravenous administration of atropine sulfate ( $0.04 \mathrm{mg} / \mathrm{kg}$ and propranolol $(0.2 \mathrm{mg} / \mathrm{kg})$. Upper panel shows changes at 10 seconds (vagal inhibition); the bottom panel shows alterations at 10 min upright position (sympathetic induced). It is to be noted the sympathetic-influenced heart rate responses in the chagasic patients. (From Marin-Neto JA et al, $1986^{33}$ ). 
the entire cardiovascular adrenergic system and favoring the installation of very high levels of circulating catecholamines, may be less appropriate than the tilting test to explore cardiac parasympathetic denervation. Using this less exacting test, it was possible to demonstrate adrenergic dysfunction of sinus control (46), avoiding the masking of possibly involved focal lesions by the compensation obtained with the diffuse response of the sympathetic system, as is the case for dynamic exercise. Similarly, the attenuation of the low-frequency component during spectral analysis of chronotropic variability in chagasic patients is consistent with the occurrence of sympathetic depression (19) (Fig. 6).

\section{PATHOLOGICAL SIGNIFICANCE OF CARDIOVASCULAR AUTONOMIC DYSFUNCTION}

With the exceptions mentioned earlier, the pathological involvement of the cardiovascular neurovegetative system in Chagas' disease may be considered to be a recognized fact on the basis of the results obtained in many studies carried out independently. However, its physiopathological role in the triggering of chronic Chagas' heart disease continues to be controversial. This situation is in contrast to the data obtained in the study of digestive chagasic lesions which have led to the recognition of the obligatory nature of denervation as the major, if not the exclusive, pathogenetic factor of megaesophagus and megacolon $(9,35,52)$. The physiopathogeny of Chagas' heart disease is definitely more complex, perhaps also because the heart is a much more phylogenetically evolved organ with consequent much more elaborate structure and function.

As an example of the difficulty in characterizing the real importance of autonomic dysfunction in chronic Chagas' heart disease, it should be emphasized that, in contrast to what occurs in digestive tract disease (52), it has not been possible to demonstrate convincingly in humans the presence of a state of denervation hypersensitivity to the cholinergic agent, as predicted by the Cannon law, despite some results suggesting this anomaly in $T$. cruzi-infected rats submitted to administration of metacholine and to electric vagal stimulation (37).

The initial theory, founded on anatomical observations, of heart disease with decreased parasympathetic activity $(34,35)$, implying a constant functional predominance of the sympathetic division, met the following apparently insoluble conceptual obstacles: a) it is not possible, even in experimentai models, to demonstrate relative or absolute adrenergic hyperactivity $(26,45,46) ; b)$ in contrast, sympathetic denervation occurs in Chagas' disease, even though less intensely, as determined anatomically (1) and functionally (46); c) heart disease clinically manifesting as myocardial dysfunction and disorders of generation and conduction of electric stimuli is detected in regions where the disease is apparently caused by parasite strains relatively devoid of neurotropism $(9,31,70)$; d) even in endemic areas where denervation is clearly detectable, there is no significant correlation between its functional expression and the presence of dysrhythmia and/or myocardial depression. On this basis, there are intensely denervated patients with normal contractile performance and no arrhythmia, side by side with other occasional chagasic patients who present severe disorders of rhythm and/or heart failure, with preservation of a practically normal pattern of autonomic response to pharmacological and physiological tests $(49,62)$; e $)$ also, from an anatomical viewpoint, the absence of a correlation between denervation and clinical course, type of death and pathological characteristics of the chagasic heart has been emphasized $(40,41) ; f$ ) even if the physiological and pharmacological principles of the classical division of the autonomic system into sympathetic and parasympathetic components continue to be conceptually maintained, modern studies have pointed out the difficulty in distinguishing them in anatomical and functional terms at the intimate level in the innervated organ (71).

Despite these criticisms of the neurogenic theory of chagasic heart disease, which was supported by quite compelling experimental results (56), it is plausible to admit that, as a contributing mechanism, autonomic denervation may represent a relevant, if not primary or exclusive, factor in the pathogenesis of this cardiopathy, conferring on it peculiar characteristics when compared to the other affections of cardiac muscle.

One should also recognize the limitations of the methods employed in anatomopathological and physiological studies carried out to determine possible autonomic alterations at the ventricular level in chagasic hearts. For example, there are no studies comparable to those about the pathological involvement of atrial innervation and of the conduction system in this structure. Similarly, with rare exceptions (study of atrioventricular conduction [22]), the physiological studies have been limited to the effects of denervation on the sinus node. However, the literature recognizes the importance of ventricular performance in functional modulation (69). 

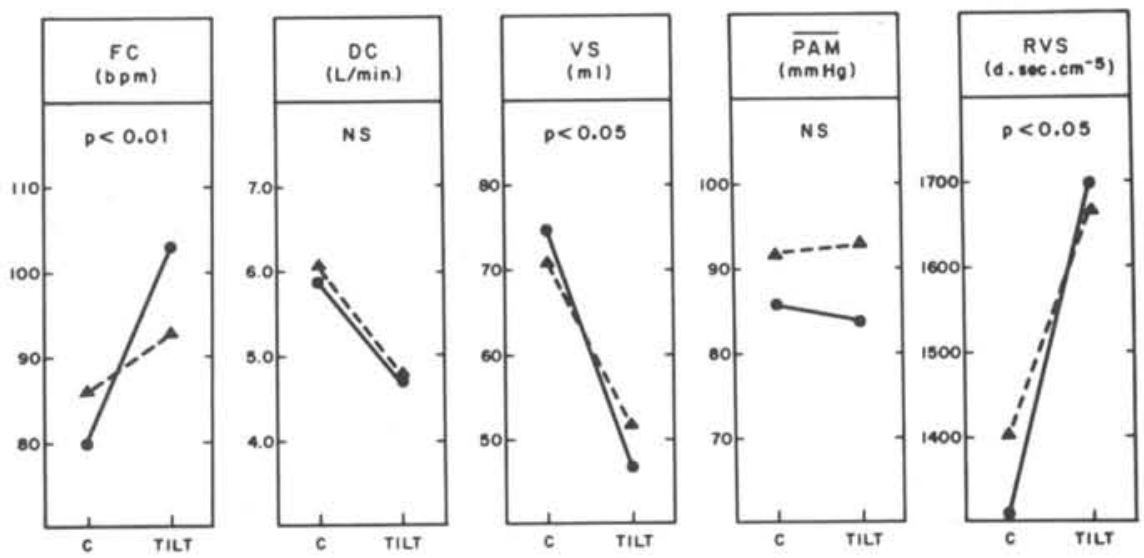

Figure 8. Hemodynamic alterations following passive changes in body position: normal controls (solid lines and circles) and chagasic patients (dashed lines and triangles). In the chagasic group the abnormal chronotropic response (FC) appears to have no effects on cardiac output (DC) and systemic arterial pressure (PAM) as compared to normal subjects. However, patients have greater decrease in stroke volume (VS) associated to higher increase in systemic vascular resistance (RVS).

On the other hand, there is a lack of evolutionary studies correlating anatomical, myocardial and rhythmic function in chagasic patients. Work on this subject has been underway in our laboratory for the past ten years, and may possibly contribute to the elucidation of the controversial aspects discussed above. Indeed, it would be illogical to conclude that an involvement as marked as that of the neurovegetative system in Chagas' disease is pathogenetically irrelevant. Its true prevalence in the general chagasic population is unknown, but approximate estimates of 20 to $25 \%$ may be deduced for the most intense degrees of denervation in unselected samples studied in Ribeirão Preto (47,52). Another essential characteristic derived from recent functional studies is that parasympathetic dysfunction, although varying individually from minimal degrees to absolute degrees of depression, can be detected by increasingly more sophisticated methods in groups representing all clinical forms-indeterminate, digestive, cardiopathic - of the disease $(28,68)$.

At least when there is an advanced degree of denervation, the chagasic heart is deprived of one of the most relevant mechanisms of the so-called cardiovascular reserve of homeometric self-regulation (66). The rapid increase in heart rate is a component of the circulatory adaptation to the wide variety of situations in which venous return, the systemic metabolic flow demand or the ventricular afterload are acutely altered. Under these conditions, the denervated chagasic heart start to depend predominantly on heterometric adjustments, with the occurrence of more conspicuous variations in cardiac volume than those detected in normal individuals from the viewpoint of autonomic control. Indeed, it has been clearly shown that the pattern of the hemodynamic response to physical effort can deviate from normality in chagasic patients even when resting values are fully normal (26). In some of these patients, the quotient of the variation in cardiac output to the increase in oxygen consumption imposed by effort was found to be below the lower normal limit, reflecting an inadequate response to physical effort. However, perhaps more significantly, instead of increasing at the expense of increased only by the ejection of a greater volume per systole (26). It may be proposed that these patients suffer a strong chronic stimulus for the use of the reserve mechanism represented by heart dilatation to satisfy the habitual increases in blood flow demands. This may represent a deleterious effect on the circulatory dynamics of chagasic individuals primarily due to cardiac denervation. 
Chagasic patients also seem to have peculiar functional characteristics with respect to the regulation of systemic arterial pressure. The attenuation of the hypertensive response in the phase of thoracic decompression of the Valsalva maneuver is typically slower than in normal individuals (44). Furthermore, during isometric exercise, denervated chagasic patients maintain a hypertensive pattern comparable to that of normal subjects. However, whereas a tachycardiadependent increased flow occurs in those controls, in chagasic patients, who cannot respond to the effort stimulus with tachycardia, the increase in systemic arterial pressure is essentially due to the elevation in peripheral vascular resistance (48). One may speculate that this hemodynamic behavior implies the presence of a frequent increase in circulatory afterload for ventricular ejection during routine daily activities. Theoretically, this may represent a constant factor of chronic stress imposed on ventricular performance, which possibly contributes to the installation and/or aggravation of the myocardial lesions intrinsically due to the aggression imposed on the heart by the direct and/or indirect action of $T$. cruzi. Chagasic patients with cardiac dysautonomy also compensate for their deficient chronotropic response to postural variations with responses of systemic vascular resistance sharply differing from those detected in normal individuals (45) (Fig. 8).

If these are conceivable physiopathological possibilities in terms of circulatory dynamics, it is interesting to propose that autonomic dysfunction will probably contribute to the typical disorders of generation and conduction of electric stimuli detected in chronic Chagas' heart disease (9). Furthermore, although a preliminary study did not demonstrate a correlation between sinus dysautonomy and ventricular dysrhythmia (62), one may propose that, as is the case for the autonomic disequilibrium and triggering of ventricular fibrillation observed at times in the acute phase of not very extensive myocardial infarctions, the sudden death observed in chagasic patients is very possibly due to mechanisms depending on dysautonomy (58). This interpretation is coherent with the reports of small, highly denervated hearts by pathologists who perform autopsies on chagasics who died suddenly $(9,68)$. We should also point out the possible effect of altered parasympathetic control of the coronary microcirculation, with repercussions on regional flow and myocardial metabolism (50).

\section{CHAGAS' DISEASE AS AN INTRINSIC MODEL OF AUTONOMIC DENERVATION}

The occurrence of extensively denervated human hearts with practically normal ventricular performance and the consequent absence of the nonspecific effects of cardiac failure $(29,51)$ provides a unique opportunity for physiological studies of the cardiovascular system (6). However, the following limitations exist about the use of denervation of chagasic etiology as a spontaneous experimental model: a) the dysfunction is not restricted to one of the autonomic divisions; b) denervation does not involve all patients and there is an undeniable geographic influence; c) the individual degree of denervation is variable; d) several anatomical sites of the autonomic system are partially affected at the afferent and central levels, and obviously mainly at the efferent level.

With respect to these restrictions, we should mention the observation of enzymatic diversity among $T$. cruzi strains suggesting that variation of the etiological agent may explain the different clinical manifestations (52). It should also be pointed out that efforts have been made to characterize the differences among Trypanosomatidae species using molecular biology methods and phylogenetic analysis $(3,20,30)$.

Within the above limitations, the study of patients with Chagas' heart disease selected by presenting an intense degree of denervation has permitted the understanding of relevant aspects of cardiovascular physiology. To illustrate, we shall mention the original report in the international literature that tachycardia evoked in humans by the standing position has a biphasic mechanism (46). At first there is a reduction of vagal tonus not demonstrable in chagasic patients, and predominantly adrenergic stimulation occurs later. These experimental results illustrate the contribution of the chagasic model to research in the area of physiological circulation.

Application of simple, noninvasive autonomic tests with no risk for chagasic patients in different geographic regions may not only clarify the controversial physiopathological aspects discussed above, but also permit new advances in the understanding of cardiovascular functionality itself. Finally, it will be necessary to reevaluate in human studies the possibility delineated in experimental studies of the reversibility of nervous lesions detected in the acute phase of $T$. cruzi infection (43). 


\section{RESUMO}

O envolvimento patológico do sistema neurovegetativo na moléstia de Chagas é fato reconhecido com base em numerosos estudos independentes in vivo e post mortem. Essas investigaçōes incluem o homem e diferentes espécies animais. Tenha-se presente, na interpretaçāo desse envolvimento patológico, a complexidade da organizaçāo dos componentes autonômicos e a

limitação metodológica. Aceitas algumas ressalvas, porém realçando-se a exclusão de efeitos inespecíficos da insuficiência cardíaca, conclui-se ser a cardiopatia chagásica modelo experimental de denervaçāo, adequado para a compreensão da

fisiopatologia cardiovascular. Se isso aproveita à biologia médica e comparativa, não há como negar que todos os estudos se ressentem da carência de melhor compreensão da estrutura molecular das diferentes espécies de Trypanosomatidae. Tal entendimento pode conduzir-nos à elucidação das discrepâncias entre investigaçōes realizadas em diferentes áreas geográficas, năo só quanto à presumivel lesão autonômica, como também ao seu grau e à sua exteriorização clínica.

\section{REFERENCES}

1. ALCÂNTARA, F.G. - Denervação dos gânglios cardíacos intramurais e cervicotorácicos na moléstia de Chagas. Rev Goiana Med 16: 159-177, 1970.

2. ALMEIDA, H.O.; TEIXEIRA, V.P.A.; ARAUJO, W.F. \& GOBBI, H. - Alterações do sistema nervoso autônomo intracardíaco em chagásicos com e sem "megas". Rev Goiana Med 29: 147-156, 1983.

3. AMORIM, D.S. \& AMORIM, D.S. - Philogenetic approaches to the study of immunology and parasitology: some comments on potential research programs. Braz J Med Biol Res 25: 967-971, 1992.

4. AMORIM, D.S.; CHAMBERS, R.J.; BECK, W.; SOMERS, K.; MANÇO, J.C. \& GALlO JR., L. - Comparative observations of the impairment of autonomic responses in chronic Chagas' heart disease and in African myocardiopathies. Cardiology 55: 321-332, 1970.

5. AMORIM, D.S.; GODOY, R.A.; MANÇO, J.C.; TANAKA, A. \& GALLO JR., L. - Effects of acute elevation in blood pressure and of atropine on heart rate in Chagas'disease. A preliminary report. Circulation 38: 289-294, 1968.

6. AMORIM, D.S.; MANÇO, J.C.; GALLO JR.,L. \& MARINNETO, J.A. - Chagas' heart disease as an experimental model for studies of cardiac autonomic function in man. Mayo Clin Proc 57: 48-60, 1982.

7. AMORIM, D.S.; MELLO DE OLIVEIRA, J.A.; MANÇO, J.C.; GALLO JR., L. \& MEIRA DE OLIVEIRA, J.S. Chagas' heart disease: First demonstrable correlation between neuronal degeneration and autonomic impairment. Acta Cardiológica 28: 431-440, 1973.

8. AMORIM, D.S. \& OLSEN, E.G.J. - Assessment of heart neurons in dilated (congestive) cardiomyopathy. $\mathbf{B r}$ Heart J 47: 11-18, 1982.
9. ANDRADE, Z.A. \& ANDRADE, S.G. - Patologia. In: Brener, Z. \& Andrade, A. eds. Trypanosoma cruzi e doença de Chagas. Rio de Janeiro: Editora Guanabara Koogan SA. 1979. p. 199-248.

10. BÖHM, G.M. - Quantitative study of the intrinsic innervation of the heart in endomyocardial fibrosis and African idiopathic cardiopathies. Rev Inst Med Trop São Paulo 10: 84-87, 1968.

11. BRANDÃO, H.J.S. - Moléstia de Chagas experimental. Estudo quantitativo de neurônios simpáticos e parassimpáticos. O Hospital 61: 1014-1028, 1962.

12. BRASIL, A. - Autonomical sino-atrial block: A new disturbance of the heart mechanism. Arq Bras Cardiol 8: 159-212, 1955.

13. CAEIRO, T.F.; PALMERO, H.A. \& IOSA, D. - Estudio del reflejo barorreceptor en la enfermedad de Chagas. Medicina (Buenos Aires) 40: 27-32, 1980.

14. CHAGAS, C. \& VILELA, E. - Forma cardíaca da tripanosomíase americana. Mem Inst Oswaldo Cruz 14: 5 61, 1922.

15. CHAPADEIRO, E.; LOPES, E.R. \& PEREIRA, F.E.L. Desnervaçāo parassimpática e hipertrofia do miocárdio em chagásicos crônicos. Rev Inst Med Trop São Paulo 9: 4042, 1967.

16. CICONELLI, A.J. - Estudo quantitativo dos neurônios do plexo hipogástrico inferior em ratos normais e em infectados experimentalmente pelo Trypanosoma cruzi. São Paulo, 1963 [Tese - Fac Med Ribeirão Preto, USP].

17. ECKBERG, D.L.; DRABINSKY, M. \& BRAUNWALD, E. - Defective cardiac parasympathetic control in patients with heart disease. N Engl J Med 285: 877-883, 1970.

18. EMDIN, M.; BIANCHINI, S.; MACERATA, A. et al. Characterization of the cardiovascular autonomic influence through time frequency spectrum analysis. Computers in cardiology, IEEE Computer Society, 1992. p. 319-322. 
19. EMDIN, M.; MARIN-NETO, J.A.; CARPEGGIANI, C. et al. - Heart rate variability and cardiac denervation in Chagas' disease. J Amb Monit 5:251-257, 1992.

20. ENGMAN, D.M.; REDDY, L.V.; DONELSON, J.E. \& KIRCHHOFF, L.V. - Trypanosoma cruzi exhibits inter-and intra-strain heterogeneity in molecular karyotype and chromosomal gene location. M Bioch Paras 22: 115-123, 1987.

21. EWING, D.J.; CAMPBELL, I.W.; BURT, A.A. \& CLARKE, B.F. - Vascular reflexes in diabetic autonomic neuropathy. Lancet II: 1354-57, 1973.

22. FARIA, M.A.M.; SILVA, E.R. \& DIAS, C.E.N. - Efeitos da acetil-beta-metil-colina (metacolina) em pacientes com a infecção crônica pelo $T$. cruzi. Estudo eletrocardiográfico controlado. Rev Inst Med Trop São Paulo 10: 171-177, 1968.

23. FERREIRA, A.L. - Alterações do testículo e do epidídimo de cobaias infectados experimentalmente com Trypanosoma cruzi. 1968 [Tese - Fac Med Ribeirão Preto, USP].

24. GAAN, D.; MAHONEY, M.P.; ROWLANDS, D.J. \& JONES, A.W. - Postural hypotension in amyloid disease. Am Heart J 84: 395-400, 1972.

25. GALLO JR., L.; MACIEL, B.C.; MANÇO, J.C. \& MARINNETO, J.A. - Limitations of facial immersion as a test of parasympathetic activity in man. J Physiol 396: 1-10, 1988.

26. GALLO JR., L.; MARIN-NETO, J.A.; MANÇO, J.C.; RASSI, A. \& AMORIM, D.S. - Abnormal heart rate responses during exercise in patients with Chagas' disease. Cardiology 60: 147-162, 1975.

27. GALLO JR., L.; MORELO-FILHO, J.; MACIEL, B.C. et al. - Evaluation of the autonomic nervous system of the heart in male patients with mitral valve prolapse syndrome using respiratory sinus arrhythmia and dynamic exercise. Cardiology 76: 433-441, 1989.

28. GALLO JR., L.; MORELO-FILHO, J.; MACIEL, B.C.; MARIN-NETO, J.A.; MARTINS, L.E.B. \& LIMA-FILHO, E.C. - Functional evaluation of sympathetic and parasympathetic system in Chagas' disease using dynamic exercise. Cardiovasc Res 21: 922-927, 1987.

29. GOLDSTEIN, R.E.; BEISER, G.D.; STAMPFER, M. \& EPSTEIN, S.E. - Impairment of autonomically mediated heart rate control in patients with cardiac dysfunction. Circ Res 36: 571-578, 1975.

30. GOMEZ, E.; VALDEZ, A.M.; PINERO, D. \& HERNANDEZ, R. - What is a genus in the Trypanosomatidae family? Philogenetic analysis of two small rRNA sequences. M Biol Evol 8: 254-259, 1991.

31. GUEVARA, J.F.; BLANDÓN, R.; JOHNSON, C.M.; SOUSA, H.O. \& LEANDRO, I. - Aspectos clínicos, anatomopatológicos y terapéuticos de la enfermedad de Chagas en Panamá. Arq Bras Cardiol 30: 140, 1977.

32. IOSA, D.J.; CAIEIRO, T.; PALMERO, H. et al. - Abnormal hyperventilation test in chronic Chagas' disease. J Aut Nerv Syst 2: 87-92, 1980.

33. JUNQUEIRA JR., L.F.; GALLO JR., L.; MANÇO, J.C.; MARIN-NETO, J.A. \& AMORIM, D.S. - Subtle cardiac autonomic impairment in Chagas' disease detected by baroreflex sensitivity testing. Braz J Med Biol Res 18: 171$178,1985$.

34. KÖBERLE, F. - Cardiopathia parasympaticopriva. München Med Wschr 101: 1308, 1959.

35. KÖBERLE, F. - Enteromegaly and cardiomegaly in Chagas'disease. Gut 4: 399-405, 1963.

36. KÖBERLE, F.; COSTA, R.B.; OLIVEIRA, J.A.M. \& OLIVEIRA, J.S.M. - Patologia da moléstia de Chagas. Medicina (CARL) 5: 5, 1972.

37. KRIEGER, E.M. \&; ALCÂNTARA, F.G. - The autonomic heart rate regulation of rats with chronic Chagas' disease. Acta Physiol Lat Am 11: 260, 1961.

38. LOPES, E.R. - Contribuição ao estudo dos gânglios cardíacos (sistema nervoso autônomo) em chagásicos crônicos. Hospital (Rio) 70: 265, 1966.

39. LOPES, E.R. - Estudo comparativo dos gânglios subepicárdicos nas cardiopatias chagásicas crônica, reumática e hipertensiva. Rev Inst Med Trop São Paulo 12: 365, 1970.

40. LOPES, E.R.; CHAPADEIRO, E.; ALMEIDA, H.O. \& ROCHA, A. -: Contribuição ao estudo da anatomia patológica dos corações chagásicos falecidos subitamente. Rev Soc Bras Med Trop 9: 269-282, 1975.

41. LOPES, E.R.; CHAPADEIRO, E. \& ROCHA, A. - Anatomia patológica do coração na forma indeterminada. In: Cançado, J.R. \& Chuster, M. eds. Cardiopatia Chagásica. Fundação Carlos Chagas, Belo Horizonte, MG, 1985.

42. LOPES, E.R. \& TAFURI, W.L. - Involvement of the autonomic nervous system in Chagas' heart disease. Rev Soc Bras Med Trop 16: 206, 1983.

43. MACHADO, C.R.S.; MACHADO, A.B.M. \& CHIARI, C.A. - Recovery from heart norepinephrine depletion in experimental Chagas' disease. Am J Trop Med Hyg 27: 20-24, 1978.

44. MANÇO, J.C.; GALLO JR., L.; GODOY, R.A.; FERNANDES, R.G. \& AMORIM, D.S. - Degeneration of the cardiac nerves in Chagas'disease. Further studies. Circulation 40: 879-885, 1969.

45. MARIN-NETO, J.A. - Respostas circulatórias a alterações passivas de postura ("tilting test") na cardiopatia chagásica crônica. 1975. 156 p. [Tese - Fac Med Ribeirão Preto, USP].

46. MARIN-NETO, J.A.; GALLO JR., L.; MANÇO, J.C.; RASSI, A. \& AMORIM, D.S. - Mechanisms of tachycardia on standing: studies in normals individuals and in chronic Chagas' heart patients. Cardiovase Res 14: 541-550, 1980.

47. MARIN-NETO, J.A.; GALLO JR., L.; MANÇO, J.C.; RASSI, A. \& AMORIM, D.S. - Postural reflexes in chronic Chagas' heart disease. Heart rate and arterial pressure responses. Cardiology 60: 343-357, 1975.

48. MARIN-NETO, J.A.; MACIEL, B.C.; GALLO JR., L.; JUNQUEIRA JR., L.F. \& AMORIM, D.S. - Effect of parasympathetic impairment on the haemodynamic response to handgrip in Chagas' heart disease. Brit Heart J 55: 204 210, 1986.

49. MARIN-NETO, J.A.; MACIEL, B.C.; GALLO JR., L.; MANÇO, J.C.; TERRA-FILHO, J. \& AMORIM, D.S. - 
Effect of lowering left atrial pressure on the arterial baroreflex control of heart rate in patients with congestive heart failure. In: Sleight, P. ed. Arterial Baroreceptors and Hypertension. Oxford University Press, England, 1980: p. 499-509.

50. MARIN-NETO, J.A.; MARZULLO, P.; MARCASSA, C. et al. - Myocardial perfusion abnormalities in chronic Chagas' disease. Assessment with Thallium-201 scintigraphy. Am J Cardiol 69: 780-784, 1992.

51. MARIN-NETO, J.A.; PINTYA, A.O.; GALLO JR., L. \& MACIEL, B.C. - Abnormal baroreflex control of heart rate in decompensated congestive heart failure and reversal after compensation. Am J Cardiol 67: 604-610, 1991.

52. MENEGHELLI, U.G. - Chagas'disease: a model of denervation in the study of digestive tract motility. Brazilian J Med Biol Res 18: 255-264, 1985.

53. MILES, M.A.; PÓVOA, M.M.; PRATA, A.; CEDILLOS, R.A.; SOUZA, A.A. \& MACEDO, V. - Do radically dissimilar Trypanosoma cruzi strains (Zymodemes) cause Venezuelan and Brazilian forms of Chagas' disease? The Lancet, 1338-1340, 1981.

54. MOTT, K.E. \& HAGSTROM, J.W.C. - The pathologic lesions of the cardiac autonomic nervous system in chronic Chagas myocarditis. Circulation 31: 273-286, 1965.

55. OLIVEIRA, J.S.M. - A natural human model of intrinsic heart nervous system denervation: Chagas' cardiopathy. Am Heart J 110: 1092-1098, 1985.

56. OLIVEIRA, J.S.M. - Cardiopatia chagásica experimental. Rev Goiana Med 15: 77-133, 1969.

57. PAGANO, M.A.; BASSÓM, S.; ARISTIMUÑO, G.G.; COLOMBI, A. \& SICA, R.E.P. - Electromyographical findings in human chronic Chagas'disease. Arq NeuroPsiquiat 36: 316, 1978.

58. OLIVEIRA, J.S.M. \& KÖBERLE, F. - Vinte e cinco anos da teoria neurogênica. In: Modernos Conhecimentos sobre Doença de Chagas. Op cit, 248-272.

59. PALMERO, H.A.; CAEIRO, T.F. \& IOSA, D.J. - Distinctive abnormal responses to tilting test in chronic Chagas' disease. Klin Wochenschr 58: 1307-1311, 1980.

60. PALMERO, H.A.; CAIEIRO, T.F.; IOSA, D.J. et al - Effect of Chagas' disease on arterial blood pressure. Am Heart J 97: 38-42, 1979.

61. PALMERO, H.A.; IOSA, D.J. \& CAEIRO, T.F. - Disfunción del sistema nervioso autónomo en la enfermedad de Chagas crónica. Rev Arg Cardiol 47: 152-159, 1979.

62. PINTYA, A.O.; MARIN-NETO, J.A.; MACIEL, B.C. \& GALLO JR., L. - Parassistolia em cardiopatas chagásicos crônicos com disritmia ventricular. Arq Bras Cardiol 44: 261-265, 1985.
63. RAMOS, J.A. \& CARVALHAL, S. - Moléstia de Chagas. Evolução de conceito. In: Cançado, J.R. ed. Doença de Chagas. Belo Horizonte, Minas Gerais, Brasil, 1968: p. 401420.

64. RIBEIRO JORGE, P.A.; MODESTO, N.P. \& CARVALHAL, S.S. - Sobre os neurônios e a coronariografia "post-mortem" na cardiopatia chagásica crônica. Arq Bras Cardiol 23: 101 108, 1970.

65. RIBEIRO DOS SANTOS, R. \& SILVA, J.S. - Doença de Chagas: resposta imune humoral e celular. Rev Goiana Med 26: 115-213, 1980.

66. SARNOFF, S.J. \& MITCHELL, J.H. - The regulation of the performance of the heart. Am J Med 34: 147-154, 1961.

67. SICA, R.E.P.; FILIPINI, D.; PANIZZA, M. et al Involvement of the peripheral sensory nervous system in human chronic Chagas'disease. Medicina (Buenos Aires) 46: 662-668, 1986.

68. SOUSA, A.C.S.; MARIN-NETO, J.A.; MACIEL, B.C.; GALLO JR., L. \& AMORIM, D.S. - Cardiac parasympathetic impairment in gastrointestinal Chagas' disease. The Lancet, I-8539: 985, 1987.

69. STRATTON, J.R.; PFEIFFER, M.A. \& HALTER, J.B. - The hemodynamic effects of sympathetic stimulation combined with parasympathetic blockade in man. Circulation 75: 922 929, 1987.

70. SUÁREZ, J.A. - Los ganglios neurovegetativos intracardíacos en la patogenia de la miocarditis chagásica. Gaz Med Bahia 69: 73-104, 1969.

71. TAFURI, W.L. - Contribuição da microscopia eletrônica para o conhecimento da patogenia da doença de Chagas experimental humana. In: Modernos Conhecimentos sobre Doença de Chagas. Op cit, 1981. p. 221-235.

72. TAFURI, W.L. - Light and electron microscope studies of the autonomic nervous system in experimental and human American trypanosomiasis. Virchows Arch Abt A Path Anat 354: 136-149, 1971.

73. TAFURI, W.L. - Pathogenesis of lesions of the autonomic nervous system of the mouse in experimental acute Chagas' disease. Am J Trop Med Hyg 19: 405-417, 1970.

74. TAFURI, W.L. \& BRENER, Z. - Lesões do sistema nervoso autônomo do camundongo albino na fase crônica da tripanosomíase cruzi experimental. Rev Inst Med Trop São Paulo 8: 177-183, 1966.

75. VIEIRA, C.B. - A forma nervosa crônica da doença de Chagas vista pelo clínico geral. Rev Goiana Med 12: 31 48, 1966. 